\title{
DCD on Mechanism of Improving Nitrogen Utilization and Applica- tion in Production of Slow-Release Fertilizers
}

\section{Cheng Sun*}

Academician Studio of the Rural Education Development Center, World Academy of Productivity Science, Beijing, 102600, China

\begin{tabular}{l}
\hline ARTICLE INFO \\
\hline Article history \\
Received: 19 March 2020 \\
Revised: 26 March 2020 \\
Accepted: 24 April 2020 \\
Published Online: 30 April 2020 \\
\hline Keywords: \\
DCD \\
Mechanism \\
Slow-Release fertilizer
\end{tabular}

\section{The Composition, Properties and Uses of DCD}

$\mathrm{D}$ CD molecular formula is $\mathrm{C}_{2} \mathrm{H}_{4} \mathrm{H}_{4}$, structural formula is $\left(\mathrm{NH}_{2}\right)_{2} \mathrm{CNCN}$, molecular weight is 84.08 , white crystal, slightly bitter taste, non-volatile, non-moisture absorption. Easily soluble in water, ethanol, acetone, liquid ammonia, ammonia water, etc. Each $100 \mathrm{ml}$ of water $\left(25^{\circ} \mathrm{C}\right)$ dissolves about $4 \mathrm{~g}, 100 \mathrm{ml}$ ethanol dissolves about $1.7 \mathrm{~g}, 100 \mathrm{ml}$ acetone dissolves about $0.7 \mathrm{~g}, 100 \mathrm{ml}$ of liquid ammonia dissolves about 4-8g. Reaction with acid can generate guanidines, and reaction with alkali can generate melamine.

DCD is an ideal nitrification inhibitor. It can effectively inhibit the formation of nitrate ammonia in the soil, inhibit the activity of nitrosating bacteria, and slow down or delay the oxidation of $\mathrm{NH}_{4}$ to $\mathrm{NO}_{3}$. $\mathrm{NO}_{3}$ can be directly absorbed and utilized by crops, but it is easily leached and produces denitrification, forming $\mathrm{NO}_{2}$, causing envi-

\section{ABSTRACT}

This paper introduces the composition, properties and uses of DCD, the effect of DCD on various crop, summaries the fertilizer effect test of fertilizer Nano slow release agent, analyzes the economic benefit analysis of fertilizer Nano slow release agent. ronmental pollution. The test results show that the peak of nitrate nitrogen in nitrogen fertilizer without DCD was formed at 32 days, while the peak period of nitrate nitrogen in nitrogen fertilizer with DCD appeared at about 62 days, which was delayed by 30 days.

DCD has an ammonia stabilizing effect. Nitrogen fertilizer mainly has three forms, namely amide nitrogen, ammonium nitrogen and nitrate nitrogen. $\mathrm{NH}_{3}$ volatilization loss is common in farmland application. Generally, the loss in paddy field accounts for more than $50 \%$ of the total nitrogen loss. $\mathrm{NH}_{3}$ volatilization loss accounts for more than $30 \%$ of the total nitrogen loss. This kind of volatilization loss shows different volatilization characteristics and different processes on different nitrogen fertilizer varieties. The volatilization loss of urea and ammonium sulfate occurs after a period of time with the soil. The initial volatilization of urea and ammonium sulfate into the farmland is much lower than that of ammonium bicarbonate. Ammonium bicarbonate is directly decomposed due

*Corresponding Author:

Cheng Sun,

Academician Studio of the Rural Education Development Center, World Academy of Productivity Science, Beijing, 102600, China;

E-mail: sc@nassg.org 
to its active molecules, so the $\mathrm{NO}_{3}$ concentration is high and the initial volatilization amount is large. DCD has a significant ammonia stabilizing effect. Mix DCD into ammonium bicarbonate in proportion, and perform ammonia volatilization rate comparison experiment with ordinary ammonium bicarbonate at $43{ }^{\circ} \mathrm{C}$ to determine the volatilization of the two. When the volatilization reaches $1 \%$ residual amount It took 10 days for ammonium bicarbonate, 12 days for DCD ammonium bicarbonate, and the time was extended by 1.2 times; the volatilization loss was 3 , $4,5,6,7$, and 8 days, and the daily reduction of the volatilization loss was 9 , respectively. 12, 16, 14, 12, 9 percentage points. This ammonia stabilizing effect of DCD, the results of the indoor simulated cultivation experiment showed that it increased the effective nitrogen storage rate in the soil by $12.5 \%$.

According to practical research results, mixing DCD with urea and carbon into the soil can reduce the loss of ammonia nitrogen by $30 \%$, and the amount of organic matter in the soil has doubled. The organic compound DCD is a nano material that can reduce the $\mathrm{pH}$ value of the soil by $0.2-0.4$, thereby increasing the adsorption strength of soil colloids and clay particles to ammonia ions.

The practical application of DCD has improved the utilization rate of chemical fertilizers and reduced the amount of chemical fertilizers applied. The amount of organic soil material in the soil has doubled, improved the soil aggregate structure, reduced the soil $\mathrm{pH}$ value, and has significant effects on soil ecological restoration effect.

\section{The Effect of DCD on Various Crops}

According to the Shenyang Agricultural Technology Extension Station and the Shenyang Institute of Ecology of the Chinese Academy of Sciences, a systematic field experiment, demonstration and extension of DCD has been carried out in more than ten counties and districts in Shenyang, and a large amount of scientific data has been obtained. The cumulative promotion area of peanuts, soybeans, vegetables and fruit trees has reached more than 2 million mu, which has achieved significant economic benefits and has been recognized by the majority of farm-

Table1. Multi-point test results of slow-release urea applied to corn in 1998

\begin{tabular}{|c|c|c|c|c|c|c|}
\hline process & Test location & $\begin{array}{c}\text { Yield per } \\
\text { mu(kg) }\end{array}$ & $\begin{array}{l}\text { To increase production } \\
\text { rate }(\mathrm{kg} / \mathrm{mu})\end{array}$ & $\begin{array}{l}\text { To increase produc- } \\
\text { tion rate }(\%)\end{array}$ & $\begin{array}{l}\text { Economic benefits } \\
\text { (yuan } / \mathrm{mu})\end{array}$ & $\begin{array}{c}\text { Average yield increase } \\
(\%)\end{array}$ \\
\hline The urea & Xincheng Area & 601 & 0 & 0 & 0 & 0 \\
\hline The urea +DCD & Qingshuitai Town & 633 & 32 & 5.32 & 24.8 & 9.72 \\
\hline The urea & Sunongtun Area & 594 & 0 & 0 & 0 & \\
\hline The urea +DCD & Chenxiangtun Town & 664 & 70 & 11.78 & 59.0 & \\
\hline The urea & Dongling Area & 565 & 0 & 0 & 0 & \\
\hline The urea + DCD & Gaokan Town & 608 & 43 & 7.61 & 34.7 & \\
\hline The urea & Dongling Area & 485 & 0 & 0 & 0 & \\
\hline The urea +DCD & Wangbin township & 540 & 55 & 11.34 & 15.5 & \\
\hline The urea & Donging Area & 535 & 0 & 0 & 0 & \\
\hline The urea +DCD & Zhujia Town & 593 & 58 & 10.84 & 48.2 & \\
\hline The urea & Kangping County & 585 & 0 & 0 & 0 & \\
\hline The urea +DCD & Liangjiazi Farm & 622 & 37 & 6.32 & 29.3 & \\
\hline The urea & Yuhong Area & 521 & 0 & 0 & 0 & \\
\hline The urea + DCD & Luojiatun Township & 604 & 83 & 15.93 & 70.7 & \\
\hline The urea & Yuhong Area & 598 & 0 & 0 & 0 & \\
\hline The urea +DCD & Laobian Township & 654 & 56 & 9.36 & 56.4 & \\
\hline The urea & Faku Town & 765 & 0 & 0 & 0 & \\
\hline The urea + DCD & Yuanzhong Field & 841 & 76 & 9.93 & 64.4 & \\
\hline The urea & Xinchengzi Area & 556 & 0 & 0 & 0 & \\
\hline The urea+DCD & Huangjia Township & 605 & 49 & 8.81 & 40.1 & \\
\hline
\end{tabular}

Table 2. Multi-point test results of slow-release urea in rice in 1998

\begin{tabular}{|c|c|c|c|c|c|c|}
\hline process & Test location & Yield per mu(kg) & $\begin{array}{l}\text { To increase produc- } \\
\text { tion rate }(\mathrm{kg} / \mathrm{mu})\end{array}$ & $\begin{array}{c}\text { To increase produc- } \\
\text { tion rate }(\%)\end{array}$ & $\begin{array}{c}\text { Economic benefits } \\
(\text { yuan } / \mathrm{mu})\end{array}$ & $\begin{array}{c}\text { Average yield } \\
\text { increase }(\%)\end{array}$ \\
\hline The urea & Yuhong Area & 610 & 0 & 0 & 0 & 0 \\
\hline The urea + DCD & Yuhongtai Township & 653 & 43 & 7.05 & 47.6 & 9.98 \\
\hline The urea & Faku Country & 483 & 0 & 0 & 0 & \\
\hline The urea + DCD & Fengbeibao Township & 550 & 67 & 13.87 & 76.4 & \\
\hline The urea & Faku Country & 546 & 0 & 0 & 0 & \\
\hline The urea + DCD & Yiniubao Township & 592 & 46 & 8.42 & 51.2 & \\
\hline The urea $+\mathrm{DCD}$ & Shifuo Town & 662 & 83 & 14.34 & 95.6 & \\
\hline The urea & Dongling Area & 529 & 0 & 0 & 0 & \\
\hline The urea + DCD & Gucheng Township & 562 & 33 & 6.24 & 35.6 & \\
\hline
\end{tabular}


ers. The statistics of the test results are shown in Table 1-5 below.

Table 1 The yield comparison test of basal application or top-dressing of DCD-containing slow-release urea and ordinary urea of corn crops showed that slow-release urea increased the yield by $5.32 \%-15.93 \%$ compared with ordinary urea, and the average yield rate was $9.72 \%$, and the economic benefit per mu increased by $24.8-70.7$ yuan, with an average value of 46.28 yuan per mu.

The rice yield measurement results in Table 2 show that slow-release urea increases the grain yield by $33-83$ $\mathrm{kg}$ per mu compared with ordinary urea, with an average increase of $54.4 \mathrm{~kg}$; the increase rate is $6.24-14.34 \%$. The average yield increase rate is $9.98 \%$, and the average economic income per mu is 62.28 yuan. Slow-release urea is applied as a one-time base fertilizer when rice seedlings are transplanted, which can eliminate the 4-5 top-dressing process. If weeding with pesticides, it can achieve no cultivating.

The application of slow-release urea for peanuts has a higher yield increase, more than 2 knots per plant, $1 \mathrm{~g}$ increase in 100-grain weight, the yield increased by 5 percentage points, the yield per acre increased by $64.5 \mathrm{~kg}$, the yield increased by $23.98 \%$, and the economic income per acre increased by 189.5 yuan.

Soybean application of slow-release urea has obvious yield increase benefits. From the performance of the plant, the number of seeds increased by 3-8, the weight of 100seed increased by $0.7-1.7 \mathrm{G}$, the average yield per mu increased by $34 \mathrm{~kg}$, the yield increase rate was $13.7 \%$, and the economic benefit per mu increased by 67.33 yuan.

The use of slow-release urea in fruit trees has a relatively high yield increase and economic benefits, with an average yield increase rate of $22.29 \%$, increasing economic income by 467 yuan per mu; and slow-release urea can promote early ripening of fruits and increase fruit size due to the effect of DCD.

In summary, the application of DCD on field crops, cash crops, and fruit trees has achieved stable yield and income increase benefits. The yield increase rate on field crops is $5.32 \%-15.93 \%$, and the annual rate is $9.72 \%$; the application increase rate on oil crops $10.50 \%-23.98 \%$, with an average of $16.28 \%$; the increase rate of application on fruit trees is $22.2 \%$, all of which have obvious yield increase benefits.

\section{Summary of Fertilizer Effect Test of Fertil- izer Nano Slow Release Agent}

"Century Tianwang" fertilizer nano slow-release agent is composed of natural minerals, nano-organic compound materials, and trace elements. It integrates urease inhibi-

Table 3. Experimental results of slow-release urea for peanut in Liaozhong County in 1998

\begin{tabular}{cccccc}
\hline process & $\begin{array}{c}\text { Number of } \\
\text { pods(per) }\end{array}$ & $\begin{array}{c}\text { Hundred grain } \\
\text { weight }(\mathrm{g})\end{array}$ & Yield per mu(kg) & $\begin{array}{c}\text { Increase production } \\
(\mathrm{Kg} / \mathrm{mu})\end{array}$ & $\begin{array}{c}\text { rate of growth(\%) } \\
\text { Economic benefit }(\mathrm{yuan} / \mathrm{mu})\end{array}$ \\
\hline The urea & 11.0 & 18.0 & 269.0 & 0 & 0 \\
The urea+DCD & 13.0 & 19.0 & 333.5 & 64.5 & 23.98 \\
\hline
\end{tabular}

Table 4. Multi-point test results of slow-release urea applied to soybean in 1998

\begin{tabular}{|c|c|c|c|c|c|c|c|}
\hline process & Test location & $\begin{array}{c}\text { Number of } \\
\text { seeds(grain) }\end{array}$ & $\begin{array}{c}\text { Hundred grain } \\
\text { weight }(\mathrm{g})\end{array}$ & $\begin{array}{c}\text { Yield per } \\
\mathrm{mu}(\mathrm{kg})\end{array}$ & $\begin{array}{c}\text { Increase production } \\
(\mathrm{Kg} / \mathrm{mu})\end{array}$ & rate of growth(\%) & $\begin{array}{c}\text { Economic bene- } \\
\text { fit(yuan/mu) }\end{array}$ \\
\hline The urea & Kaiyuan Town & 28.8 & 18.1 & 157 & 0 & 0 & 0 \\
\hline The urea $+\mathrm{DCD}$ & Agency Farm & 31.8 & 18.8 & 180 & 23 & 14.65 & 46.3 \\
\hline The urea & Seed Company & 43.9 & 16.9 & 256 & 0 & 0 & 0 \\
\hline The urea $+\mathrm{DCD}$ & & 48.5 & 17.8 & 297 & 41 & 16.02 & 81.8 \\
\hline The urea & & 52 & 21.2 & 362 & 0 & 0 & 0 \\
\hline The urea $+\mathrm{DCD}$ & & 60 & 22.9 & 400 & 38 & 10.50 & 73.9 \\
\hline
\end{tabular}

Table 5. Application of slow-release urea on fruit trees in 1998

\begin{tabular}{|c|c|c|c|c|c|}
\hline process & Test tree species & Yield per mu(kg) & $\begin{array}{c}\text { Increase production } \\
(\mathrm{Kg} / \mathrm{mu})\end{array}$ & rate of growth(\%) & Economic benefit(yuan/mu) \\
\hline The urea & Big Sand Apricot & 24 & 0 & 0 & 0 \\
\hline The urea $+\mathrm{DCD}$ & Tree & 30 & 300 & 25.00 & 356 \\
\hline The urea & \multirow{2}{*}{ Plum Tree } & 32 & 0 & 0 & 0 \\
\hline The urea $+\mathrm{DCD}$ & & 39 & 350 & 21.88 & 556 \\
\hline The urea & \multirow{3}{*}{ Hawthorn Tree } & 20 & 0 & 0 & 0 \\
\hline The urea $+\mathrm{DCD}$ & & 24 & 240 & 20.00 & 428 \\
\hline The average & & & 297 & 22.29 & 467 \\
\hline
\end{tabular}


tion, nitrification inhibition, ammonia stabilization, and plant growth regulation. A kind of fertilizer additive with the comprehensive effect of function mechanism. It is also a natural bio-nano composition for soil ecological restoration and agricultural pollution control. Its appearance is a white or dark brown powder, with good stability, not easy to volatilize and not deteriorate. It is mixed and used in a certain proportion with nitrogen fertilizers, which has strong adhesion and good affinity; fertilizer nano slow-release agents can also be added to compound fertilizers, in the formula of compound fertilizer production process, long-acting slow-release compound fertilizer and compound fertilizer are produced. The main functions of fertilizer nano slow-release agents are:

(1) It can be used as a soil conditioner to promote the formation of soil aggregate structure and improve soil physical properties.

(2) It can be used as a plant growth agent. The polyphenol structure in the molecule can be used as oxygen reduction. Therefore, it strengthens the respiration of plants, promotes the absorption of nutrients by plants, promotes root growth, enhances crop resistance, and promotes

Early maturity increases crop yield and improves crop quality.

(3) It can not only improve the utilization of N, P, K but also effectively inhibit the urease activity in the soil and act as a urease inhibitor.

(4) It is also an ideal nitrification inhibitor. It can effectively inhibit the formation of nitrate-nitrogen in the soil, inhibit the activity of nitrosating bacteria, and slow down or delay the rate of oxidation of NH4 to NO3.

(5) Has ammonia stabilizing effect. Mixing slow-release agents with urea and carbon into the soil can reduce the loss of ammonia nitrogen by $30 \%$, while the fixed amount of organic matter in the soil more than doubles.

(6) The organic compound in the fertilizer nano slow release agent is a kind of nanomaterial, which can reduce the $\mathrm{pH}$ value in the soil, thereby increasing the adsorption strength of soil colloids and clay particles to ammonia ions.

Fertilizer nano slow-release agent is a new high-tech material for soil ecological restoration with DCD and natural humic acid as the main raw materials. The material is a new high-tech material for soil ecological restoration, which integrates urease inhibition, nitrification inhibition, ammonia stabilization, and plant growth stimulators. New type fertilizer slow release agent. Multiple applications of variable nitrogen fertilizers are used as a base application. During the entire growth period of the crop, no topdressing can be used to extend the effective period of nitrogen fertilizer and increase the nitrogen utilization rate. According to the Liaoning Provincial Soil Station in 1997, 8 test points were arranged on corn and rice. The test results can be summarized as follows.

\subsection{Materials and Methods}

(1) Test materials: Diammonium, urea, ammonium chloride, fertilizer slow release agent

(2) Test soil: Paddy soil, brown soil, meadow soil

(3) Test crop: Corn, rice

(4) Field trial design: Set 4 treatments (the treatment changes or less than 4 treatments are also taken into consideration), each treatment is set to be repeated three times, arranged in random blocks, and the plot area is 20 square meters.

\subsection{Experimental Effect of Fertilizer Nano Slow-Release Agent on Corn}

(1) Test results in five sites in Liujiahe, Fengcheng city and Xima, Dengta city

I. Conventional fertilization (Diammonium $10 \mathrm{~kg} / \mathrm{mu}+$ urea $10 \mathrm{~kg} / \mathrm{mu}$ )

II. Conventional fertilization + slow release agent 0.6 $\mathrm{kg} / \mathrm{mu}$

III. Urea $20 \mathrm{~kg} / \mathrm{mu}$ + slow release agent $1.2 \mathrm{~kg} / \mathrm{mu}$

Analysis of Test results

From Table 6 to Table 7, it can be seen that the 2 and 3 places where the slow-release agent is applied. From Table 6 to Table 8 , it can be seen that the growth and development of corn is significantly better than that of conventional fertilization in the 2 and 3 treatments of the

Table 6. Investigation Form of Corn Growth Period

\begin{tabular}{cccccccc}
\hline $\begin{array}{c}\text { Experiment loca- } \\
\text { tion }\end{array}$ & Process & Sowing period & $\begin{array}{c}\text { Emergence peri- } \\
\text { od }\end{array}$ & $\begin{array}{c}\text { Pull seedlings } \\
\text { peroid }\end{array}$ & Tasseling period & Grouting period & Maturity peroid \\
\hline Feng City & I & 4.24 & 5.9 & 6.18 & 7.22 & 8.10 & 9.20 \\
Liu Jia He & II & 4.24 & 5.5 & 6.17 & 7.21 & 8.9 & 9.19 \\
& III & 4.24 & 5.9 & 6.18 & 7.22 & 8.10 & 9.20 \\
Deng Ta & I & 5.15 & 5.20 & 6.10 & 7.20 & 7.19 & 10.3 \\
Xi Ma & II & 5.15 & 5.20 & 6.10 & 7.18 & 10.2 \\
& III & 5.15 & 5.20 & 6.10 & & 10.3 \\
\hline
\end{tabular}


Table 7. Investigation Form of Corn Growth Characters

\begin{tabular}{|c|c|c|c|c|c|c|c|}
\hline $\begin{array}{c}\text { Experiment } \\
\text { location }\end{array}$ & Process & Plant height(cm) & Leaf color & $\begin{array}{l}\text { Ears per mu } \\
\quad(\text { per })\end{array}$ & $\begin{array}{l}\text { Number of grains } \\
\text { per spike (per) }\end{array}$ & 100 grain weight & \\
\hline Feng City & I & 291 & green & 2364 & 498.0 & 37.0 & \\
\hline \multirow[t]{2}{*}{ Liu Jia He } & II & 294 & Dark green & 2464 & 556.0 & 38.8 & \\
\hline & III & 292 & Dark green & 2398 & 532.0 & 37.6 & \\
\hline Deng Ta & I & 220 & $\begin{array}{l}\text { Darker } \\
\text { green }\end{array}$ & 2623 & 634.2 & 32.1 & \\
\hline \multirow[t]{2}{*}{ Xi Ma } & II & 218 & $\begin{array}{l}\text { Darker } \\
\text { green }\end{array}$ & 2634 & 634.4 & 33.3 & \\
\hline & III & 216 & $\begin{array}{l}\text { Darker } \\
\text { green }\end{array}$ & 2628 & 636.1 & 34.0 & \\
\hline $\begin{array}{l}\text { Experiment } \\
\text { location }\end{array}$ & Process & Plant height $\left(\mathrm{cm}^{*} \mathrm{~cm}\right)$ & $\begin{array}{l}\text { Ear number } \\
\text { per } / \mathrm{m}^{2}\end{array}$ & $\begin{array}{l}\text { Empty shot } \\
\text { rate } \%\end{array}$ & Ears per mu (per) & $\begin{array}{l}\text { Number of grains per } \\
\text { spike (per) }\end{array}$ & 100grain weight $(\mathrm{g})$ \\
\hline Deng Ta & I & $55 * 36.3$ & 5.0 & 15.5 & 2824 & 645.8 & 32.1 \\
\hline \multirow[t]{2}{*}{ Wang Jia } & II & $55 * 37.2$ & 4.8 & 12.7 & 2818 & 622.0 & 33.3 \\
\hline & III & $55 * 36.6$ & 5.0 & 15.5 & 2807 & 632.1 & 34.0 \\
\hline
\end{tabular}

Table 8. Corn Production Survey Form

\begin{tabular}{cccccccc}
\hline \multirow{2}{*}{ Test Location } & \multicolumn{2}{c}{ I } & \multicolumn{2}{c}{ II } & \multicolumn{2}{c}{ III } \\
\cline { 2 - 7 } & Yield per mu & Yield per mu & Increase yield per mu & Increase rate & Yield per mu & Increase yield per mu & Increase rate \\
\hline Fengcheng Liujiahe & 382.5 & 416.9 & 34.4 & 9.0 & 410.2 & 27.7 & 7.2 \\
Dengta Xima & 534.0 & 556.4 & 22.4 & 4.2 & 568.4 & 34.4 & 6.4 \\
Dengta Wangjia & 524.7 & 545.7 & 21.0 & 4.0 & 546.1 & 21.4 & 4.1
\end{tabular}

slow-release agent. The performance is the best. Compared with other treatments, the maturity period is 1 day earlier, the leaf color is dark green, the empty stem rate is reduced, and the number of ears per mu and 100-grain weight are increased. In terms of output, treatments 2 and 3 increase the output by $21.4-34.4 \mathrm{~kg}$ compared with 1 and the increase rate is $4.0 \%-9.0 \%$.

(2) Test results in Zhen'an district, Dandong city:

Test treatment: I Conventional fertilization (Diammonium $10 \mathrm{~kg} / \mathrm{mu}$ + urea $10 \mathrm{~kg} / \mathrm{mu}$ ) II Conventional fertilization (Diammonium $10 \mathrm{~kg} / \mathrm{mu}+$ urea $20 \mathrm{~kg} / \mathrm{mu}$ ) III Conventional fertilization $1+$ Slow release agent $0.6 \mathrm{~kg} / \mathrm{mu}$ IV Conventional fertilization $2+$ slow release agent $1.2 \mathrm{~kg} / \mathrm{mu}$

Table 9. Corn growth period, growth traits and yield survey table

\begin{tabular}{|c|c|c|c|c|c|c|c|c|c|}
\hline process & $\begin{array}{c}\text { Sowing } \\
\text { period }\end{array}$ & $\begin{array}{l}\text { Emer- } \\
\text { gence } \\
\text { period }\end{array}$ & Feast & & & $\begin{array}{r}\text { Grout } \\
\text { peric }\end{array}$ & & $\begin{array}{l}\text { Ma- } \\
\text { turi- } \\
\text { ty }\end{array}$ & $\begin{array}{c}\text { Growth } \\
\text { Period }\end{array}$ \\
\hline I & 5.3 & 5.14 & 6.27 & & 23 & 8.8 & & 15 & 9 \\
\hline II & 5.3 & 5.14 & 6.27 & & 23 & 8.8 & & 15 & 9 \\
\hline III & 5.3 & 5.14 & 6.27 & & 23 & 8.8 & & 15 & 9 \\
\hline IV & 5.3 & 5.14 & 6.27 & & 23 & 8.8 & & 15 & 9 \\
\hline $\begin{array}{l}\text { Treat- } \\
\text { ment/ } \\
\text { fertility } \\
\text { traits }\end{array}$ & \multicolumn{2}{|c|}{$\begin{array}{c}\text { Plant } \\
\text { height/ } \\
\mathrm{CM}\end{array}$} & \multicolumn{4}{|c|}{$\begin{array}{c}\text { The } \\
\text { number } \\
\text { of grains }\end{array}$} & $\begin{array}{r}100 \\
\text { we }\end{array}$ & $\begin{array}{l}\text { grain } \\
\text { eight }\end{array}$ & - \\
\hline I & \multicolumn{2}{|c|}{208} & \multicolumn{4}{|c|}{570} & & 7.4 & - \\
\hline
\end{tabular}

\begin{tabular}{ccccccc} 
II & 212 & green & 16 & 600 & 28.5 & - \\
III & 217 & $\begin{array}{c}\text { Dark } \\
\text { green }\end{array}$ & 16 & 620 & 29.9 & - \\
IV & 215 & $\begin{array}{c}\text { Dark } \\
\text { green }\end{array}$ & 16 & 600 & 29.3 & - \\
\hline $\begin{array}{c}\text { Processing } \\
\text { item }\end{array}$ & $\begin{array}{c}\text { Plot yield } \\
/ 123\end{array}$ & Average & $\begin{array}{c}\text { Yield } \\
\text { per mu/ } \\
\text { Kg }\end{array}$ & $\begin{array}{c}\text { Yield } \\
\text { increase } \\
\text { per mu }\end{array}$ & $\begin{array}{c}\text { Increased } \\
\text { produc- } \\
\text { tion rate }\end{array}$ & project \\
\hline I & 12.76 & 13.65 & 12.95 & 13.12 & 364.08 & - \\
II & 13.74 & 14.22 & 15.13 & 14.36 & 398.49 & 34.11 \\
III & 16.86 & 14.6 & 15.28 & 15.58 & 432.62 & 68.54 \\
IV & 15.56 & 14.6 & 14.18 & 14.78 & 410.15 & 46.07
\end{tabular}

It is obvious from the test results in Table 9 that all the treatments using sustained-release agents:

Obviously there is no difference in growth period, but growth traits and yield are dominant, especially treatment III. Compared with conventional fertilization I, the plant height increases by $9 \mathrm{~cm}$, the leaf color is dark green, the number of grains per ear increases by 50 grains, and the 100 -grain weight increases by $2.5 \mathrm{~g}$. The output increased by $68.5 \mathrm{~kg}$, an increase of $18.8 \%$. From the perspective of the increase in yield, Treatment III $(10 \mathrm{~kg} / \mathrm{mu}$ of diammonium $+10 \mathrm{~kg} / \mathrm{mu}$ of urea $+0.6 \mathrm{~kg} / \mathrm{mu}$ of sustained-release agent) is better than IV $(10 \mathrm{~kg} / \mathrm{mu}$ of diammonium +20 $\mathrm{kg} / \mathrm{mu}$ of urea + sustained-release agent $1.2 \mathrm{Kg} / \mathrm{mu}$ ), indicating that too much nitrogen fertilizer should not be applied to the slow-release agent. It has obvious fertilizer 
saving effect. A small amount of slow-release agent can play an ideal synergistic effect.

\subsection{Application Effect of Fertilizer Nano Slow-Re- lease Agent on Rice}

(1)Test results in Kaiyuan test site

Test treatment: I Conventional fertilization $\square$ Diammonium $10 \mathrm{~kg} / \mathrm{mu}+$ ammonium chloride $25 \mathrm{~kg} / \mathrm{mu} \square$ II Conven- tional fertilization I+ sustained release agent $1.0 \mathrm{~kg} / \mathrm{mu} \mathrm{III}$ Diammonium $10 \mathrm{~kg} / \mathrm{mu}+$ urea $15 \mathrm{~kg} / \mathrm{mu}$ IV Diammonium $10 \mathrm{~kg} / \mathrm{mu}+$ urea $15 \mathrm{~kg} / \mathrm{mu}+$ sustained release agent $0.9 \mathrm{~kg} /$ $\mathrm{mu}$ The test results and analysis are shown in Table 10.

It can be seen from Table 10 that the application of slow-release agents does not affect the growth period of rice, but obviously promotes the growth and development of rice. Compared with the control, the color of the two leaves is darkened, and the number of effective tillers,

Table 10. Rice growth period, growth traits and yield survey table

\begin{tabular}{|c|c|c|c|c|c|c|c|}
\hline $\begin{array}{l}\text { Treatment } \backslash \text { Child- } \\
\text { bearing Period }\end{array}$ & Sowing period & Planting period & $\begin{array}{l}\text { Rejuvena- } \\
\text { tion period }\end{array}$ & Tillering stage & Jointing period & Heading date & Maturity \\
\hline I & 4.9 & 5.25 & 5.31 & 6.8 & 7.11 & 8.9 & 10.2 \\
\hline II & 4.9 & 5.25 & 5.31 & 6.8 & 7.11 & 8.9 & 10.2 \\
\hline III & 4.9 & 5.25 & 5.31 & 6.8 & 7.11 & 8.9 & 10.2 \\
\hline IV & 4.9 & 5.25 & 5.31 & 6.8 & 7.11 & 8.9 & 10.2 \\
\hline $\begin{array}{c}\text { Treatment } \backslash \text { Child- } \\
\text { bearing Period }\end{array}$ & Plant height & Leaf color & $\begin{array}{l}\text { Dispensing } \\
\text { rate }\end{array}$ & Ears per mu & $\begin{array}{c}\text { Number of grains } \\
\text { per spike }\end{array}$ & Number of loam & Thousand grains \\
\hline I & 100.1 & green & 85.5 & 274680.4 & 68.1 & 21.4 & 25.1 \\
\hline II & 100.2 & yellow & 86.0 & 278680.6 & 68.9 & 24.5 & 25.6 \\
\hline III & 100.5 & green & 85.1 & 273347.0 & 68.3 & 21.6 & 25.0 \\
\hline IV & 100.9 & $\begin{array}{l}\text { green } \\
\text { yellow } \\
\text { green }\end{array}$ & 85.6 & 277347.2 & 68.0 & 23.2 & 25.9 \\
\hline $\begin{array}{c}\text { Treatment/ } \\
\text { Project }\end{array}$ & & Plot yield/123 & & $\begin{array}{c}\text { Average/ } \\
\text { kg }\end{array}$ & Yield per mu/kg & Yield increase per $\mathrm{mu} / \mathrm{kg}$ & $\begin{array}{c}\text { Increased produc- } \\
\text { tion rate/ } \%\end{array}$ \\
\hline I & 14.5 & 14.8 & 13.2 & 14.1 & 470.0 & - & - \\
\hline II & 14.8 & 15.0 & 14.2 & 14.7 & 490.0 & 20.0 & 4.3 \\
\hline III & 14.1 & 14.3 & 13.7 & 14.0 & 466.7 & - & - \\
\hline IV & 14.1 & 15.2 & 14.9 & 14.8 & 493.4 & 20.7 & 4.7 \\
\hline
\end{tabular}

Table 11. Rice growth period, growth traits and yield survey table

\begin{tabular}{|c|c|c|c|c|c|c|c|}
\hline $\begin{array}{c}\text { Treatment } \\
\text { Growth Period } \\
\end{array}$ & $\begin{array}{c}\text { Sowing } \\
\text { period }\end{array}$ & Planting period & $\begin{array}{c}\text { Rejuvenation } \\
\text { period }\end{array}$ & Tillering stage & Jointing period & Heading date & The mature stage \\
\hline I & 4.8 & 5.25 & 5.31 & 6.5 & 6.18 & 8.3 & 9.24 \\
\hline II & 4.8 & 5.25 & 5.31 & 6.5 & 6.18 & 8.5 & 9.24 \\
\hline III & 4.8 & 5.25 & 5.31 & 6.5 & 6.18 & 8.6 & 9.24 \\
\hline IV & 4.8 & 5.25 & 5.31 & 6.5 & 6.18 & 8.7 & 9.24 \\
\hline $\begin{array}{c}\text { Treatment/ } \\
\text { fertility traits }\end{array}$ & Plant height & Leaf color & Tillering stage(\%) & Ears per mu(per) & Spike grain number & Pi grain number & Thousand grains \\
\hline I & 102 & Light green & 28.9 & 106.3 & 79.5 & 25.2 & 25.4 \\
\hline II & 101 & green & 28.5 & 108.5 & 81.8 & 24.6 & 25.3 \\
\hline III & 97 & Dark green & 29.2 & 110.2 & 84.4 & 23.4 & 26.0 \\
\hline IV & 100 & Dark green & 28.8 & 109.8 & 84.1 & 23.4 & 25.8 \\
\hline $\begin{array}{l}\text { Treatment/ } \\
\text { Project }\end{array}$ & & Plot yield/123 & & $\begin{array}{c}\text { Average/ } \\
\mathrm{kg}\end{array}$ & Yield per $\mathrm{mu} / \mathrm{kg}$ & $\begin{array}{c}\text { Yield increase per } \\
\mathrm{mu} / \mathrm{kg}\end{array}$ & $\begin{array}{l}\text { Increased pro- } \\
\text { duction rate/\% }\end{array}$ \\
\hline I & 15.6 & 16.0 & 15.8 & 15.8 & 526.9 & 0 & 0 \\
\hline II & 16.5 & 16.6 & 16.8 & 16.6 & 553.6 & 26.7 & 5.1 \\
\hline III & 17.0 & 17.1 & 16.8 & 17.0 & 565.8 & 38.9 & 7.4 \\
\hline IV & 16.8 & 17.6 & 16.9 & 16.9 & 563.6 & 36.7 & 7.0 \\
\hline
\end{tabular}


ears per mu, grains per ear, Thousand-grain weights all increased. In terms of the increase in output, the increase rates were $4.3 \%$ and $5.7 \%$, respectively.

(2) Test results in Haicheng test site

Test treatment: I Conventional fertilization (Diammonium $10 \mathrm{~kg} / \mathrm{mu}$ + ammonium chloride $25 \mathrm{~kg} / \mathrm{mu}$ )

II Conventional fertilization I+ sustained release agent 1.0 $\mathrm{kg} / \mathrm{mu}$ III Ammonium Chloride $40 \mathrm{~kg} / \mathrm{mu}+$ slow release agent $1.6 \mathrm{~kg} / \mathrm{mu}$ IV Diammonium $10 \mathrm{~kg} / \mathrm{mu}+$ urea $15 \mathrm{~kg} /$ $\mathrm{mu}+$ sustained release agent $0.9 \mathrm{~kg} / \mathrm{mu}$

See Table 11 for test results and analysis

From the test results in Table 11, it can be seen that the slow-release agent has no effect on the growth period of rice, but it has an effect on the growth and yield of rice. The treatment with the slow-release agent has dark green leaf color, number of grains per ear, number of grains, Thousand-grain weights were increased compared to the control, the empty rate also decreased, the yield rate increased by $5.1 \%, 7.4 \%$ and $7.0 \%$, and the average yield rate was $6.5 \%$.

(3) Test results in two sites in Dashiqiao, Yingkou

Test Treatment

I Conventional fertilization (Diammonium $10 \mathrm{~kg} / \mathrm{mu}$ + ammonium chloride $15 \mathrm{~kg} / \mathrm{mu}$ )

II Conventional fertilization I+ sustained release agent $1.0 \mathrm{~kg} / \mathrm{mu}$

See Table 12 for test results and analysis

It can be seen from Table 12 that the application of slow-release agents has no effect on the growth period of rice; however, it has a greater impact on the growth characteristics. Compared with the control, the stem thickness, ear number per mu, grain number per ear, and 1000-grain weight all increase, An increase of 5.6\%-10.6\%, a thousand-grain weight increase of 0.1-0.5 grams, an increase of $79.8-113.5 \mathrm{~kg}$ per mu, an increase rate of $12.7 \%-19.6 \%$, an average of $16.15 \%$.

\subsection{Conclusion}

(1) Simultaneous application of nitrogen fertilizer in corn base, combined with slow-release agent, can increase the utilization rate of nitrogen fertilizer. Extend the effective period of nitrogen fertilizer. One-time basal application of nitrogen fertilizer without topdressing can achieve no defertilization during the whole growth period of corn, and the leaf color will be darkened to improve the fertility of corn the number of ears per mu, the number of ears per ear, and the weight of 100 kernels all increased.

(2) Compared with the control, the application of slow-release agent in rice has a darker leaf color, an increase in the number of effective tillers and the number of ears per ear, the number of grains per mu per ear increased by $0.7-19$, and the thousand-grain weight increased by 0.1-0.9 grams. Fat phenomenon.

(3) Apply a small amount of slow-release agent (usually

Table 12 Rice growth period, growth traits and yield survey table

\begin{tabular}{|c|c|c|c|c|c|c|c|c|}
\hline Test Location & & & $\begin{array}{l}\text { Planting } \\
\text { period }\end{array}$ & $\begin{array}{l}\text { Rejuvenation peri- } \\
\text { od }\end{array}$ & $\begin{array}{l}\text { Tillering } \\
\text { stage }\end{array}$ & Jointing period & Heading date & Maturity \\
\hline \multirow{2}{*}{ Dashiqiao Water Source } & I & 4.16 & 5.26 & 5.30 & 6.2 & 7.1 & 8.4 & 10.3 \\
\hline & II & 4.16 & 5.26 & 5.30 & 6.2 & 7.1 & 8.4 & 10.9 \\
\hline \multirow{2}{*}{ Dashiqiao Water Source } & I & 4.14 & 6.2 & 6.6 & 6.9 & 7.2 & 8.7 & 10.9 \\
\hline & II & 4. 14 & 6.2 & 6.6 & 6.9 & 7.2 & 8.7 & 10.9 \\
\hline Test Location & Process & $\begin{array}{l}\text { Plant } \\
\text { height }\end{array}$ & Thick stem & Ears per mu & Spike & $\begin{array}{l}\text { Number of } \\
\text { loam(per) }\end{array}$ & $\begin{array}{l}\text { Thousand } \\
\text { grains(\%) }\end{array}$ & \\
\hline \multirow{2}{*}{ Dashiqiao Water Source } & I & 100.7 & 2.10 & 351611 & 1228 & 11,1 & 13.2 & \\
\hline & II & 99.7 & 2.25 & 409451 & 135.8 & 11.3 & 23.7 & \\
\hline Dashiqiao Water Source & I & 100.1 & 2.30 & 369515 & 110.4 & 10.1 & 20.2 & \\
\hline Treatment/Project & & Plot yield/123 & & Yield per $\mathrm{mu} / \mathrm{kg}$ & $\begin{array}{c}\text { Yield } \\
\text { increase per } \\
\mathrm{mu} / \mathrm{kg}\end{array}$ & $\begin{array}{l}\text { Increased pro- } \\
\text { duction rate } / \%\end{array}$ & & \\
\hline \multirow{2}{*}{ Dashiqiao Water Source } & I & 21.2 & 18.5 & 16.4 & 18.9 & 630.3 & - & - \\
\hline & II & 21.7 & 21.2 & 409451 & 135.8 & 11.3 & 79.8 & 127 \\
\hline \multirow{2}{*}{ Dashiqiao Water Source } & I & 15.0 & 17.7 & 18.1 & 17.3 & 577.0 & - & - \\
\hline & II & 20.2 & 22.4 & 19.4 & 20.7 & 690.5 & 113.5 & 19.6 \\
\hline
\end{tabular}


Table 13. Comparison table of application of slow-release nitrogen fertilizer to increase yield and income of several field crops

\begin{tabular}{|c|c|c|c|c|c|c|c|}
\hline \multirow{3}{*}{ Crop varieties } & \multicolumn{2}{|c|}{ Slow release nitrogen fertilizer } & \multicolumn{3}{|c|}{ Ordinary nitrogen fertilizer } & \multicolumn{2}{|c|}{ Increase production and income } \\
\hline & $\begin{array}{l}\text { Fertilizer amount } \\
\qquad \mathrm{kg} / \mathrm{mu}\end{array}$ & $\begin{array}{l}\text { Yield } \\
\mathrm{Kg} / \mathrm{mu}\end{array}$ & $\begin{array}{l}\text { Fertilizer amount } \\
\qquad \mathrm{Kg} / \mathrm{mu}\end{array}$ & $\begin{array}{l}\text { Yield } \\
\mathrm{Kg} / \mathrm{mu}\end{array}$ & $\begin{array}{c}\text { Increase produc- } \\
\text { tion } \\
\mathrm{Kg} / \mathrm{mu}\end{array}$ & $\begin{array}{l}\text { Increased produc- } \\
\quad \text { tion rate } \%\end{array}$ & $\begin{array}{l}\text { Value added per } \\
\mathrm{mu}\end{array}$ \\
\hline & \multicolumn{2}{|c|}{ Urea + slow release agent } & \multicolumn{5}{|c|}{ Urea } \\
\hline Corn & 20 & 686.4 & 20 & 604.1 & 82.3 & 13.6 & 57.6 \\
\hline Rice & 25 & 731.8 & 25 & 666.8 & 65.0 & 9.8 & 65.0 \\
\hline Wheat & 10 & 249.5 & 10 & 227.0 & 22.5 & 9.9 & 27.0 \\
\hline Soybeans & 7 & 253.9 & 7 & 222.3 & 31.6 & 14.2 & 63.0 \\
\hline Peanut & 7 & 667.0 & 7 & 583.0 & 129.0 & 23.9 & 193.5 \\
\hline Beet & 25 & 3293.8 & 25 & 2792.6 & 501.2 & 17.9 & 160.4 \\
\hline
\end{tabular}

$0.6 \mathrm{~kg} / \mathrm{mu})$ to corn under normal fertilization conditions, and a good yield increase effect can be obtained, with an increase rate of $4.1 \%-18.8 \%$.

(4) Under the conditions of normal application of nitrogen fertilizer, the application of slow-release agents will increase the yield of rice. The yield per mu can be increased by $20-113 \mathrm{~kg}$, and the yield increase rate is $4.3 \%$ $19.6 \%$.

(5) Due to the severe drought and typhoon in Liaoning in 1997, the test was affected to a certain extent. However, it can be seen from the test results that the application of slow-release agents can enhance the stress resistance of crops.

\section{Economic Benefit Analysis of Fertilizer Nano Slow Release Agent}

In the process of experimental demonstration and popularization and application in the past few years, the cumulative application area of various field crops has reached more than 3 million mu, and fertilizer slow-release agents have shown significant social and economic benefits.

(References in this chapter: Zhang Zhiming, Feng Yuanqi and other materials on DCD's mechanism and application effects)

\section{References}

[1] Feng Yuanqi. Mechanism of long-acting nitrogen fertilizer and its application in slow-release compound fertilizer[J]. Chemical Fertilizer Design, 2003(05):56-58.

[2] Zhong Yi. Nitrogen release characteristics of bag-controlled slow-release fertilizer and its application effect in Leizhulin [D]. Hangzhou: Zhejiang Agriculture and Forestry University, 2018.

[3] Changhai Zhang, Guiping Zhang, Zhiguo Chen. Research on nitrogen fertilizer operation technology of Super rice[J].Agricultural Science and Technology,2014(6):100-103. 